III-1 | 2011

Contemporary Reassessment of William James a Century Later

\title{
The Reception of William James in Continental Europe
}

Jaime Nubiola

\section{CpenEdition}

Journals

Electronic version

URL: http://journals.openedition.org/ejpap/869

DOI: $10.4000 /$ ejpap.869

ISSN: 2036-4091

Publisher

Associazione Pragma

\section{Electronic reference}

Jaime Nubiola, "The Reception of William James in Continental Europe », European Journal of Pragmatism and American Philosophy [Online], III-1 | 2011, Online since 01 July 2011, connection on 19 April 2019. URL : http://journals.openedition.org/ejpap/869 ; DOI : 10.4000/ejpap.869

This text was automatically generated on 19 April 2019

\section{c) $($ ) (8)}

Author retains copyright and grants the European Journal of Pragmatism and American Philosophy right of first publication with the work simultaneously licensed under a Creative Commons AttributionNonCommercial-NoDerivatives 4.0 International License. 


\title{
The Reception of William James in Continental Europe
}

\author{
Jaime Nubiola
}

\section{AUTHOR'S NOTE}

A previous version of this text was presented at the William James centennial celebration held in the University of Coimbra in November of 2010. I am very grateful to Edmundo Balsemao Pires for his kind invitation to take part in that event. A previous version was presented in September 2010 in a conference held in Oxford by the Rothermere American Institute. I am really grateful to Giovanni Maddalena, Erik Norvelle, Jason Panone and Hilary Putnam for their help, and to the Department of Philosophy of Harvard University for its generous hospitality to prepare this paper. I am also indebted with Howard G. Callaway and Rossella Fabbrichesi for their useful suggestions to my presentation in Coimbra.

\section{Introduction}

1 "Growing up zigzag" is the title that Robert Richardson assigns to the section dedicated to William James's early years in his well-known biography. Travelling with his family, James attended schools not only in the United States and England, but in France, Switzerland and Germany, and was also privately tutored. According to Louis Menand, "when William was thirteen [1855], William and Henry had attended together at least ten different schools" (Menand 2001: 92; Lewis 1991: 72). On May 26th 1858, William writes to his friend Ed Van Winkle from London:

We have now been three years abroad. I suppose you would like to know whether our time has been well spent. I think that as a general thing, Americans had better keep their children at home. I myself have gained in some things but have lost in others. We have got a general knowledge \& education which we could never have 
acquired at home, but on the other hand we have not gone through the general routine which we should have done in America. (Corr. 4: 16; Richardson 2006: 23)

This early observation of sixteen-year-old William already suggests a permanent tension in James. Throughout all his life he was "a nostalgic cosmopolitan, flying from perch to perch, now yearning for home, now equally eager to escape" (Perry 1936: I, 177). He was fluent in French and German, and at least competent in Italian, ${ }^{1}$ and traveled a lot through-out Europe. As Jack Barbalet has written,

By the time he died in 1910 at the age of 68 years, William James was undoubtedly the most influential American thinker of his period; indeed, of any period. His European reputation was possibly even higher than his standing in America. James not only represented to European thinkers the American advances in psychology and philosophy, for which he was largely responsible, but he entered into the formation of contemporary European thought as much as he did American.

In view of the horizon of the William James centennial celebration, the aim of my paper is to try to provide a vivid sense of James's personal involvement with Europe and particularly with Continental philosophy, giving some indications about the different countries. The topic is genuinely immense, and I will give only some thick brush strokes for some countries, paying particular attention to Spain as a case study. Hence, my paper will be divided into three sections, after this introduction: 2) Europe in James; 3) James in Europe: friends and interlocutors; 4) James in Spain: translations and readers. A number of names and facts will be mentioned, since they provide the general framework for understanding the reception of William James in Continental Europe, but I will try in particular to high-light the personal relations between William James and some of the most relevant European thinkers of his time.

\section{Europe in James}

It is not easy to establish what in James was European and what was American. With the exception of the year he passed in Newport (1858-59), he lived in Europe from the 13th year of his life until the 19th, "the most fertile years in new experiences, where the spirit is most eager to know," as his early biographer Le Breton (1929: 34) writes, and he returned to Europe once and again for health and academic reasons.

5 James came back to Europe in 1867-68 to recover from his nervous breakdown. He attended physiology lectures in Berlin, stayed in Dresden, took the baths in Teplitz, visited Heidelberg, Geneva, Paris and in November of 1868 he returned to Harvard not really recovered, but to try to finish his medical degree (Simon 1998: 102-14). As is well known, William James credited the reading in April 1870 of the French philosopher Charles Renouvier (1815-1903) and learning of "his definition of free will - sustaining of a thought because I choose to when I might have other thoughts" (William James Diary, 30 April 1870; Simon 1998: 127), as a key step in his recovery from depression.

He came back to Europe in October of 1873 (London, Paris, Florence, Rome, Venice, Dresden) and returned to Cambridge in March of 1874 to teach anatomy and physiology at Harvard. In 1880 James was appointed assistant professor of philosophy at Harvard and spent the summer in Europe for "intellectual sustenance": he hoped to meet some of the European philosophers with whom he had been corresponding and to expand his small philosophical 'club' (Simon 1998: 169). He stayed in London, Heidelberg and the Swiss Alps. James would return to Europe several times in the following years: the sabbatical 
year 1882-83, alone and "rattling around Europe at a furious pace" (Richardson 2006: 224-5): Germany, Prague, Venice, Paris and London; with his wife and children in 1892-93; sabbatical and convalescence in Europe throughout 1899-1902; trip to the Mediterranean with Henry, 1905; Hibbert Lectures at Oxford 1908-09; and the final trip to Europe, MarchAugust 1910, as a last attempt to recover his failing health.

Hundreds of European places, thousands of letters, providing a detailed testimony of his feelings, his meetings and his experiences. Europe invigorated him with its strength and prosperity: "he felt there manly and energetic" (Simon 1998: 251). In this sense it may also be observed that the Europe familiar to James was - besides England - France, Germany and Switzerland, and in those countries he usually stayed in rich and developed environments. In particular, as Perry notes, "the lack of art in the environment made it impossible that James should ever be completely reconciled to the "American scene" (Perry 1936: II, 254). For instance, on December 1908, James writes to Charles A. Strong from Cambridge,

On the whole I don't wonder at your choosing to live more and more abroad. We're a thousand years behindhand in so many things; and the attained social character of European civilizations generally is more erfreulich than those mere suggestions and possibilities of good, that are perhaps more abundant here. (Corr. 12: 138)

In sum, as Perry writes of James, "when he was in America he longed for Europe; when he was in Europe he longed for America [...]. His weariness was always associated with the present and communicated a rosy and seductive quality to the absent" (Perry 1936: II, 37). During his long stays in Europe James developed a profound ambivalence towards the United States. James's answer in December of 1895 to Carl Stumpf - who had invited him to attend the International Congress of Psychology to be held in Munich in the summer of 1896 - is very revealing (Perry 1936: II, 189):

I wish for many reasons I could go. Such things keep one from fossilizing and prolong one's possibilities of "adaptation." Nevertheless I have little hope. I ruined myself financially by my last excursion en famille to Europe, and nothing but the need of foreign travel for my health could justify so speedy a repetition of the process. Moreover, it unsettles my Americanism (that tender plant) to go too often abroad, and that must be weighed against the intellectual and social advantages of the Congress. It is no light matter to feel foreign in one's native land. I am just beginning to feel American again, when this temptation comes!

As a contrast with this, I cannot resist recalling James's letter to his wife at the end of March 1905 after a two-hour walk through Naples, a Mediterranean city of the real Europe:

From $1 / 2$ past 4 to $1 / 2$ past six I walked alone through the old Naples, hilly streets, paved from house to house and swarming with the very poor, vocal with them too, their voices carry so that every child seems to be calling to the whole street, goats, donkeys, chickens, and an occasional cow mixed in, \& no light of heaven getting in doors. The street floor composed of cave like shops, the people doing their work on chairs in the street for the sake of light and in the black inside, beds and a stove visible among the implements of trade. Such light and shade, and grease and grime, and swarm, and apparent amiability would be hard to match. I have come here too late in life, when the picturesque has lost its serious reality. Time was when hunger for it haunted me like a passion, and such sights would have then been the solidest of mental food. I put up then with such inferior substitutional suggestions as Geneva \& Paris afforded - but these black old Naples streets are not suggestions, they are the reality itself - full orchestra. (Corr. 10: 575) 


\section{James in Europe: Interlocutors and Friends}

10 I have mentioned already how William James credited the reading of the French philosopher Charles Renouvier as a decisive step in his recovery from depression. In fact, the relationship and correspondence between them extended over a quarter of a century (Perry 1936: chaps. XLI-XLIII). ${ }^{2}$ Intellectual and personal friendship and fame were two really important elements in James's life. He had a lot of friends in Europe, who opened the doors to his relationships and enhanced his fame. On this issue, I love to recall the anecdote from the end of April 1905, when James was in Rome for the Fifth International Congress of Psychology:

He went to the conference hall to register, "and when I gave my name," he told Alice, "the lady who was taking them almost fainted, saying that all Italy loved me, or words to that effect." His effusive admirer called in one of the officers of the congress, who, just as impressed, implored James to give a talk at one of the general meetings. "So I'm in for it again," James admitted with delight, "having no power to resist flattery." (Corr. 11: 17; Simon 1998: 332)

11 The following year 1906, William James published in the Journal of Philosophy his wellknown paper on "G. Papini and the Pragmatist Movement in Italy." I want to quote only the opening lines:

American students have so long had the habit of turning to Germany for their philosophic inspiration, that they are only beginning to recognize the splendid psychological and philosophical activity with which France today is animated; and as for poor little Italy, few of them think it necessary even to learn to read her language. Meanwhile Italy is engaged in the throes of an intellectual rinascimento quite as vigorous as her political one. (James 1906: 337)

James describes vividly the enthusiasm for pragmatism of Giovanni Papini and the small band associated with the journal Leonardo (1903-07): Prezzolini, Vailati, Calderoni, Amendola and others. "The Italian pragmatists," James concludes the paper, "are an extraordinarily well-informed and gifted, and above all an extraordinarily free and spirited and unpedantic, group of writers" (James 1906: 341). As the reader may know, there is an historical problem here on the reception of pragmatism in Italy that only recently has started to gain due attention: the appropriation of William James by Mussolini and Italian fascism, after the first World War, in part through the mediation of Papini, but mostly from Mussolini himself, who according to Perry, "not only knew at least fragments of Jamesian doctrine and found them to his liking. He also remembers having made James's personal acquaintance." In his book published in 1935 - when il Duce still ran Italy - Perry was at pains to do justice to the whole affair (Perry 1936: II, 574-9). A thorough study is still missing, although some steps have been taken in that line suggesting that the pragmatist genealogy of fascism is truly unfounded (Diggins 1972: 221-2; Myers 1986: 414-5 and 592-3; Maddalena \& Tuzet 2007). What also can now be said is that this misappropriation of James by fascism had the result of causing in Italy an almost complete neglect of Italian pragmatism until very recently (Dal Pra 1984; Santucci 1995).

13 A highlight in the reception of William James's thought and pragmatism in Europe, and in particular in Germany, was the III International Congress of Philosophy, held in Heidelberg in September of 1908, at which the proposals of the pragmatists were in the center of the international debate. James M. Baldwin, Emile Boutroux, Wilhelm Jerusalem, 
Christine Ladd-Franklin, Emile Meyerson, Hugo Münsterberg, Eugenio d'Ors, Josiah Royce, Ferdinand C.S.Schiller, Giovanni Vailati, and many others attended the conference (Elsenhans 1908/74). Bergson figures in the program as a keynote speaker, but he was not able to attend due to an untimely illness in Switzerland and was replaced by the president of the conference, the neo-Kantian Wilhelm Windelband.

The first speaker was Josiah Royce on "The Problem of Truth in the Light of Recent Discussion" which opened the general discussion on pragmatism and truth. Royce opposed several forms of pragmatism and all relativism, suggesting as his own position the label of "Absolute Pragmatism" (Royce 1908/74). According to the reports of the conference, the traditional dominance of Kantism and neo-Kantism of Germany and France (in this country due mainly to the influence of Renouvier) had been challenged by the fresh air of pragmatism coming with juvenile strength from America and England (Ugarte de Ercilla 1908: 210-4; Alexandre 1908: 930-40; Fullerton 1908: 573-7). The core of the debate was the conflict between the relativistic stance of pragmatism and the metaphysics of idealism, between truths related to real human life and eternal truths. One of the main voices was F.C.S. Schiller arguing that the idea of an "independent, supernatural, eternal, incommutable, unachievable, inapplicable, and useless truth" was a childish delusion: for Schiller, "in its most important sense Truth was a social product" (1908/74: 711-9 and 92; Tröhler 2008: 70). In his report of the conference H. Delacroix notices de absence of William James, the "chef d'école" of pragmatism, together with Wundt, Lipps, Flournoy and a few other philosophical luminaries of the day (Alexandre 1908: 928; Delacroix 1908: 529).

James's volume of Pragmatism was also published in Germany in 1908, only one year after its original publication, translated by Wilhelm Jerusalem, the Austrian Jewish philosopher and pedagogue. Let us recall the original "Preface":

The pragmatic movement, so-called - I do not like the name, but apparently it is too late to change it - seems to have rather suddenly precipitated itself out of the air. A number of tendencies that have always existed in philosophy have all at once become conscious of themselves collectively, and of their combined mission; and this has occurred in so many countries, and from so many different points of view, that much unconcerted statement has resulted. I have sought to unify the picture as it presents itself to my own eyes, dealing in broad strokes, and avoiding minute controversy. Much futile controversy might have been avoided, I believe, if our critics had been willing to wait until we got our message fairly out.

In that preface of April 1907 William James provides further readings on pragmatism. He mentions John Dewey in America, Schiller in England, four French philosophers (Milhaud, Le Roy, Blondel and de Sailly) and a forthcoming book by Papini, but no German philosopher is referred to. In this sense, it is not unwarranted to say that pragmatism was received in Germany with hostility by the academic establishment, which leaned more towards Kantism and Hegelianism. As Perry writes, "although Ernst Mach was an important forerunner of pragmatism, while Simmel and Ostwald were greeted by James as allies, pragmatism gained only a slight foothold in Germany, and that mainly in Austria! Even the three philosophers just mentioned accepted it as an interpretation of method in the physical or social sciences rather than as a philosophy" (Perry 1937: II, 579-80).

The sympathetic correspondence with Jerusalem beginning in 1900, who was an early admirer of James and his translator into German, is very revealing. For instance, in November 1909 Jerusalem writes him from Vienna: “The misunderstandings of and the opposition against Pragmatism lies deeper than I thought at first. Science wants a 
theoretic or static, a timeless truth [...]." At the end of the letter, Jerusalem adds: "Of my translation almost 500 copies are sold, not much but more than nothing. There is hope then, that little by little we may get convertites and with their help to take arms against the barren speculations of pure logic" (Corr. 12: 361-2). As we now know, the first World War changed the entire intellectual European stage, and both pragmatism and idealism soon became part of the past. The strength of Husserl (Herzog 1995) and the attraction of Heidegger, in spite of their intellectual connections with pragmatism, eclipsed the figure of William James totally.

of course there are strong links between William James and several German scientists of his time like Hermann von Helmholtz, Wilhelm Wundt and Carl Stumpf. The continued relations between James and German universities may be perhaps epitomized by the hiring of Hugo Münsterberg to take charge of the Harvard laboratory of psychology in order to replace James (Perry 1937, II: 138-54). All the letters between William James and his German correspondents are nowadays a real treasure of intellectual delight, but it seems to me that there is no real German philosopher amongst his more active correspondents. American pragmatism and German philosophy were in opposite camps with a very difficult middle ground. ${ }^{3}$ As Hilary Putnam writes in his preface to volume 10 of James's correspondence, "absolute idealism was indeed to be swept from the scene but not by pragmatism, although pragmatist polemics may have played a part in its demise." It was replaced, first in England and later in the United States by what is now called analytic philosophy. But, "however, - Putnam adds - pragmatism is presently undergoing a revival; the story is certainly not yet finished!" (Putnam 2002: xxxii-xxxiii).

Mentioning Vienna, it is fair to make a brief reference to James's relation with Freud. Since this has already been studied (Singer 2003; Segal 2005), I want only to mention here James's impression of Freud after meeting him during the twentieth annual celebration of Clark University (Rosenzweig 1994). He writes to his Swiss friend Théodore Flournoy: "I hope that Freud and his pupils will push their ideas to their utmost limits, so that we may learn what they are. They can't fail to throw light on human nature, but I confess that he made on me personally the impression of a man obsessed by fixed ideas. I can make nothing in my own case with his dream theories" (Corr. 12: 334). In fact, the boom of Freud and psychoanalysis after first World War and the fading away of James's optimistic account of emotions has a lot to do with Freud's conception of emotions as "irrational forces that, if not properly discharged, lead to neurotic symptoms." As Barbalet concludes this comparison, "Freud's account resonated perfectly with a political, social and economic world that was experiencing not only the irrationality and violence of total war, but also economic depression and dislocation" (Barbalet 1994, and 2007).

But it is time to move to Paris, since France was the golden door for James's introduction in Europe. Not only Gaston Milhaud, Édouard Le Roy and Maurice Blondel, mentioned in the preface of "Pragmatism," but in particular Henri Bergson and Émile Boutroux were friends and interlocutors of William James in the first decade of the nineteenth century. Also, a really interesting area of research is the impact of James's thought and pragmatism on the French Catholic environment. Very recently a collection of studies on this issue has been published under the general title of The Reception of Pragmatism in France \& The Rise of Roman Catholic Modernism, 1890-1914, edited by David G. Schultenover (2009). A similar full-length study for each country would be required to get a clearer view of James's impact in Continental Europe. 
21 As Perry writes, "without any doubt the most important philosophical and personal attachment of James's later years was that which he formed with Bergson" (Perry 1937: II, 599). Henri Bergson was a towering figure in the French philosophical scene. The friendly affinity between both philosophers is clear and mutually acknowledged: "Neither philosopher ever made any claims of priority; each rejoiced to find the other in possession of the truth, and was almost extravagantly appreciative of the other's merit. The similarity of their doctrine," Perry rightly asserts, "is not complete or extraordinary - and does not disparage the originality of either" (Perry 1937: II, 600). ${ }^{4}$ I will cite only one quotation from Bergson's letter of July 20, 1905 to James:

[...] to my mind, one of the most striking arguments that one can invoke (from the external point of view) in favor of American "pragmatism" and the "new philosophy" in France is precisely that these two doctrines have established themselves independently of one another, with different points of departure and different methods. When, under such conditions, two doctrines tend to coincide, there is a good chance that both of them are in the vicinity of the truth. (Perry 1937: II, 616-7)

The second great name to be mentioned is Émile Boutroux, who was the best friend of William James in France during the last two years of James's life. Although their philosophical positions were diverse - as with Bergson - "their friendship ripened quickly into love," Perry writes. As James acknowledged six weeks before his death: "To have known you is one of the pleasantest episodes of my life, and the memory of it will always be a satisfaction" (Letter of 16 July 1910, Corr. 12: 570). Only a few months after James's death Boutroux would publish his well-known introductory book to James's life and philosophy (Boutroux 1911).

\section{The Case of Spain: Early Translations and Readers}

William James sailed on the steamer Spain from New York to Europe on October 10th, 1873 , but he did not visit Spain nor stay for any length of time in any other Spanishspeaking country throughout all his life. ${ }^{5}$ Nevertheless, James's thought and books were received early on in Spain by prominent scholars such as Miguel de Unamuno (1864-1936), José Ortega y Gasset (1883-1955), and Eugenio d'Ors (1881-1954). In fact, it is possible to assert that, contrary to a superficial impression, there is a deep affinity between the central questions of James's thought and the topics and problems addressed by the most relevant Hispanic thinkers of the twentieth century.

Without any doubt, a sign of the warm reception of William James in Spain is the early translation of a number of four of his books during his lifetime. The first translation of James into Spanish appeared as early as 1900. It was a two-volume translation of the Principles of Psychology (1890), by Domingo Barnés, a well-known Spanish educator of his time, a member of the famous InstituciónLibre de Enseñanza, and an expert in psychology and sociology. Besides the Principles, Barnés translated a dozen books by contemporary authors such as John Dewey, Henri Bergson and others. The second translation of James into Spanish was Talks to Teachers on Psychology and to Students on Some of Life's Ideals (1899), which appeared in 1904 translated by Carlos M. Soldevila. Three years later, the first translation of The Varieties of Religious Experience into Spanish was completed by Miguel Domenge Mir under the title Fases del sentimientoreligioso. Estudiosobre la naturalezahumana. 
fourth translation of James into Spanish was The Will to Believe and Other Essays in Popular Philosophy in 1909, under the title of La vidaeterna y la fe [Eternal Life and Faith]. The translator was Santos Rubiano (1871-1930), an army doctor who was a pioneer in the application of the methods and concepts of modern psychology in the Spanish army. A veteran of the Philippines and North African wars, he was trained as a psychologist at Cornell University in the United States in1916, funded by the Spanish Ministry of Public Education (Bandrés \& Llavona 1997). In that year Rubiano translated Psychology. Briefer Course, which had a second edition in 1930. After the opening page there is a photographic reproduction of a hand-written text from William James dated on the 22nd of March of 1908. The text is the following:

22.III. 08

... and am very glad to authorize you as my official translator. Believe me, dear

Doctor, with sincere and grateful regards, yours very truly.

Wm James

Dr. Santos Rubiano

Rubiano includes a lively "biographical-critical foreword" in his translation of the Briefer Course. He writes that in this book "not only does the professor speak, but also the genius and the believer," and that James "was able to create from his own personality his own method of teaching, and [that] in his personality it was possible to find not only a philosopher but a good man" (Rubiano 1916: xiii). Besides these two works, Rubiano translated Pragmatism into Spanishin 1923, and in 1924 The Meaning of Truth as well as a new translation of Talks to Teachers.

Coming now to the original production on James in the Spanish speaking countries, in 1961 Pelayo H. Fernández studied in detail how Miguel de Unamuno read William James, his frequent quotations of James and his marginal notes in the works by James in his library. Fernández's conclusion was that Unamuno's pragmatism was “original with respect to that of the American, from whom he absorbed only complementary features" (Fernández 1961: 13). However, Izaskun Martínez (2007) has convincingly argued that the abundance of facts that Pelayo Fernández lists bears witness to a permanent impact of James on Unamuno's intellectual development.

In the case of José Ortega y Gasset, John Graham published a careful study in which, after noting Ortega's hostility to American pragmatism, he reveals "many basic connections, similarities and points of identity, so that concrete influence and dependence seem more plausible than 'coincidence' between Ortega and James" (Graham 1994: 145). Graham gives evidence that Ortega read James early in his career, and that Ortega was aware of James's radical empiricism as having anticipated the central notion of his own "rationalvitalism" (Graham 1994: 147-52). His evidence of James's impact on Ortega by German sources, themselves influenced by James, is especially convincing (Donoso 1995: 499).

I want to bring attention to what Ortega writes in a footnote in his well-known What is Philosophy?: "With this I suggest that in pragmatism, aside its audacity and naivety, there is something profoundly true, even though it be centrifugal" (Ortega 1982, 41 [my italics]). If I understand this passage correctly, what Ortega is trying to say is that pragmatism is a valuable philosophical tradition, but it is alien, foreign ("centrifugal") to the mainstream of European philosophy. Moreover, as Graham noted (Graham 1994: 146), there is an autobiographical text of Ortega in which he seems to assert that pragmatism, which began outside the boundaries of the European stage, did not reach its full maturity until it was integrated in the framework of German philosophy, that is, in the mainstream of his 
own philosophical position (Ortega 1980: 14). This is for me one of the main avenues for further exploration concerning the overlapping of pragmatism and Hispanic philosophy: if one understands Ortega's thought as a German flourishing of pragmatist roots, it is possible to bring the most distinctive traits of Hispanic philosophy and James's philosophy closer.

In contrast with Ortega, Eugenio d'Ors is perhaps the Hispanic philosopher most conscious of his personal connection with American pragmatism. By 1907 he had defined himself as a pragmatist, driven by the same desires as moved his American counterparts, whom he hoped to outstrip by recognizing an aesthetic dimension of human action that could not be reduced to the merely utilitarian (d'Ors 1915: II, 373-5). In fact, d'Ors was able to meet William James in Paris on May of 1910 when James visited Boutroux at the Foundation Thiers and meet there the "intelligent young laureates at the Foundation" (Perry 1937: II, 567-9; Corr. 12: 570). Forty years later, in 1947, in his El secreto de la filosofía, which crowned his philosophical career, d'Ors generously acknowledges his debt to the American tradition (d'Ors 1947: 12). It might be said that William James was present in d'Ors' thought and writings throughout his entire life (González \& Nubiola 2007).

In brief, in Spain William James was received with enthusiasm by some young scholars like Eugenio d'Ors or José MaríaIzquierdo (1910), but the more common reaction was the hostility of the German oriented philosophers and also Scholastic thinkers (Arnáiz 1907: 617-27 and 855-67).

\section{Conclusion}

As Cushing Strout (2001) has written, James was "a cosmopolitan American patriot who could speak to the world." William James was credited by the historian H. Stuart Hughes with being "the revivifying force in European thought in the decade and a half preceding the outbreak of the First World War" (Stuart Hughes 1958: 397). I deeply agree with this position; nevertheless I am of the opinion that a full study about James's virtual disappearance from Europe after the First World War is now required.

My impression is that the general resurgence of pragmatism over the last decade has also brought about a rediscovery of William James and his thought. The recent rediscovery of James and other figures of Classic American Pragmatism might be a key factor for overcoming the naturalism of reductionistic stripe which dominates most of the contemporary philosophical scene.

\section{BIBLIOGRAPHY}

ALEXANDRE M., (1908), "IIIe Congrès International de Philosophie (Heidelberg, 31 août, 5 septembre 1908). Compte Rendu des Séances," Revue de Métaphysique et de Morale, XVI, 927-1066.

ARNÁIZ M., (1907), “Pragmatismo y humanismo,” Cultura Española, 5-6, 617-27; and 7-8, 855-67. 
BANDRÉS J. \& R. LLAVONA, (1997), “Santos Rubiano: la introducción de la psicología científica en el ejército español," Psicothema, IX/3, 659-69.

BARBALET J., (2004), “William James: Pragmatism, Social Psychology and Emotions,” European Journal of Social Theory 7, 337-53.

BARBALET J., (2007), “Classical Pragmatism, Classical Sociology: William James, Religion and Emotion," in Pragmatism and European Social Theory, P. Baert \& B. Turner, editors, Oxford, The Bardwell Press, 17-45 [jackbarbalet.com/uploads/CLASSICAL_PRAGMATISM.pdf].

BOUTROUX E., (1911), William James, Paris, Armand Colin.

DELACRoIX H., (1908), “Le IIIe Congrès International de Philosophie. (Septembre 1908),"

Revue Philosophique de la France et de l'Étranger 66, 528-45.

DIGGINS J. P., (1972), Mussolini and Fascism. The View from America, Princeton, NJ, Princeton University Press.

Donoso A., (1995), "Review of Graham's A Pragmatist Philosophy of Life in Ortega y Gasset," Hispania 78, 498-9.

ELSENHANS T., (1908/1974), Bericht über den III. Internationalen Kongress für Philosophie zu Heidelberg 1.bis 5. September 1908; Kraus reprint, Neldeln/Liechtenstein.

FERNÁNDEZ P. H., (1961), Miguel de Unamuno y William James. Un paralelopragmático, Salamanca, CIADA.

FULLERTON G. S., (1908), “The Meeting of the Third International Congress of Philosophy, at Heidelberg, August 31 to September 5, 1908," The Journal of Philosophy, Psychology and Scientific Methods, 5, 573-7.

GONZÁLEZ A. \& J. NUBiola, (2007), “William James en Eugenio d'Ors,” Anuario Filosófico XL/2, 413-33. GRAHAM J. T., (1994), A Pragmatist Philosophy of Life in Ortega y Gasset, Columbia, MI, University of Missouri Press.

HERzoG M., (1995), “William James and the Development of Phenomenological Psychology in Europe," History of the Human Sciences, VIII, 29-46.

IZQUiERDo J. M., (1910), Del Pragmatismo, Ateneo de Sevilla; reprinted in 2009. Available at [ unav.es/gep/IzquierdoDelpragmatismo.pdf].

JAMES W., (1900), Principios de psicología, translation by Domingo Barnés, Madrid, Daniel Jorro, 2 vols., 2nd edition, 1909.

JAMES W., (1906), “G. Papini and the Pragmatist Movement in Italy," Journal of Philosophy, Psychology and Scientific Methods, III, 337-41.

JAMES W., (1907-08), Fases del sentimiento religioso. Estudio sobre la naturaleza humana, translation by Miguel Domenge Mir, Barcelona, Carbonell y Esteva, 3 vols.

JAMES W., (1909), La vida eterna y la fe, translation by Santos Rubiano, Barcelona, Heinrich; reprinted as La voluntad de creer y otros ensayos de filosofía popular, Madrid, Daniel Jorro, 1922.

JAMES W., (1916), Compendio de psicología, translation by Santos Rubiano, Madrid, Daniel Jorro; 2nd edition, 1930.

JAMES W., (1923), Pragmatismo, Madrid, Daniel Jorro.

JAMES W., (1924), El significado de la verdad, Madrid, Daniel Jorro. 
JAMES W., (1924), Psicología pedagógica (para maestros). Sobre algunos ideales de la vida (para estudiantes), Madrid, Daniel Jorro.

JAMES W., (1926), The Letters of William James, edited by his son H. James, Boston, Little Brown. JOAS H., (1993), Pragmatism and Social Theory, Chicago, University of Chicago Press.

KALLEN H. M., (2001), William James and Henri Bergson. A Study in Contrasting Theories of Life \& Responses and Reviews, Bristol, Thoemmes Press.

LE BRETON M., (1929), La personnalité de William James, Paris, Hachette.

LEWIS R. W. B., (1991), The Jameses: A Family Narrative, New York, Farrar, Straus \& Giroux. MADDALENA G. \& G. TUZET, (2007), I pragmatisti italiani tra alleati e nemici, Milano, Albo Versorio. MARTÍNEZ I., (2007), William James y Miguel de Unamuno: Una nuevaevaluación de la recepción del pensamiento pragmatista en España, Doctoral diss., Universidad de Navarra, Spain.

MARTÍNEZ I. \& J. NUBIOLA, (2007), “Unamuno's Reading of The Varieties of Religious Experience and its Context," in Fringes of Religious Experience. Cross-perspectives on William James's The Varieties of Religious Experience, S. Franzese \& F. Kraemer editors, Ontos, Frankfurt, 157-68.

MENAND L., (2001), The Metaphysical Club, Farrar, Straus \& Giroux, New York.

MYERS G. E., (1986), William James: His Life and Thought, New Haven, CT, Yale University Press.

ORS E. d’, (1915), Glosari de Xenius, Tallers Gráfics Montserrat, Barcelona, II, 373- 5.

ORS E. d', (1947), El secreto de la filosofía, Barcelona, Iberia.

ORTEGA Y GASSET J., (1980), “Medio siglo de filosofía,” Revista de Occidente 3, 5-21.

ORTEGA Y GASSET J., (1982), ¿Qué es filosofía?, Madrid, Espasa-Calpe.

PERRY R. B., (1937), The Thought and Character of William James, 2 vols, Boston, Little, Brown.

PRA M. Dal, (1984), Studi sul pragmatismo italiano, Naples, Bibliopolis.

PUTNAM H., (2002), "Introduction," in The Correspondence of William James, vol. 10, Skrupselis I. \& Berkeley E. M. (eds), Charlottesville, University Press of Virginia, xxv-xlvii.

RICHARDSON R. D., (2006), William James. In the Maelstrom of American Modernism. A Biography, Boston, Houghton Mifflin.

ROYCE J., (1908/1974), “The Problem of Truth in the Light of Recent Discussion," in Berichtüber den III. InternationalenKongressfürPhilosophie, T. Elsenhans (ed.), 62-90.

ROSENZWEIG S., (1994), The Historic Expedition to America (1909). Freud, Jung and Hall the King-Maker, St. Louis, Rana House.

RUBIANO S., (1916), “William James. Bosquejo biográfico. Nota crítica sobre su ideario psicológico,” in James W., Compendio de psicología, ix-xxvii.

SANTUCCI A., (1995), Empirismo, pragmatismo, filosofia italiana, Bologna, CLUEB.

SCHILLER F. C. S., (1908/1974), “Der Rationalistische Wahrheitsbegriff,” in Bericht über den III. InternationalenKongressfürPhilosophie, T. Elsenhans (ed.), 711-9.

SCHUltenover D. G., (2009), The Reception of Pragmatism in France \& The Rise of Roman Catholic Modernism, 1890-1914, Washington, The Catholic University of America Press. 
SEGAL R., (2005), "James and Freud on Mysticism," in William James and "The Varieties of Religious Experience": A Centenary Celebration, J. Carrette (ed.), London, Routledge, 124-32.

SIMON L., (1998), Genuine Reality. A Life of William James, New York, Harcourt Brace.

SINGER J. L., (2003), “Daydreaming, Consciousness, and Self-Representations: Empirical Approaches to Theories of William James and Sigmund Freud," Journal of Applied Psychoanalytic Studies, 5, 461-83.

SKRUPSELIS I. \& E. M. BERKELEY, (1992-2004), The Correspondence of William James, Charlottesville, VA, University Press of Virginia, 10 volumes. [It is referred as Corr. followed by the number of volume and page.]

STRout C., (2001), "William James and the Tradition of American Public Philosophers," Partisan Review 48, available at [bu.edu/partisanreview/archive/2001/3/strout.html].

STUART Hughes H., (1958), Consciousness and Society: The Reorientation of European Social Thought 1890-1930, New York, Knopf.

TRÖHLER D., (2008), "Lange as Homeland: The Genevan Reception of Pragmatism," in

T. S. Popkewitz (ed.), Inventing the Modern Self and John Dewey. Modernities and the Traveling of Pragmatism in Education, New York, Palgrave Macmillan, 61-83.

UGARTE DE ERCILLA E., (1908), “Tercer Congreso Internacional de Filosofía,” Razón y Fe, XXII, 210-4

\section{NOTES}

1. "Tell Aleck to drop his other studies, learn Italian (real Italian, not the awful gibberish I try to speak)," Letter to his wife, 31 March, 1905; Corr. 10: 575.

2. On the 2nd of November of 1872, James writes to Renouvier: "Je puis dire que par elle [votre philosophie] je commence à renaître à la vie morale," Corr. 4:430.

3. An essential study about the impact of American pragmatism in Europe, the misunderstanding of pragmatism as a utilitarian theory of truth in Germany (including some connections with Nazism) is Joas 1993. In particular, the role of Eduard Baumgarten (108-11) in this process should be taken in account.

4. On the contrasts between Bergson and James, besides Perry 1937, ch. LXXXVI, "James and Bergson: Relations and Influences," 599-617, see the volume of Kallen 2001, and Putnam (2002: xxxvi-xxxii).

5. This last section of the paper is an abridged version of the text co-authored with Izaskun Martínez on 2007.

\section{ABSTRACTS}

By the time of his death in 1910 at the age of 68 years, William James had become the most influential thinker not just of his own period, but indeed of any period. As the sociologist Jack Barbalet has written: "His European reputation was possibly even higher than his standing in America. James not only represented to European thinkers the American advances in psychology 
and philosophy, for which he was largely responsible, but he entered into the formation of contemporary European thought as much as he did American." The aim of this paper is to provide a vivid sense of James's personal involvement with European thought generally and continental philosophy specifically, giving some indications about various European countries, but with particular attention to Spain as a case study. Accordingly, the talk divides into three sections: (1) Europe in James; (2) James in Europe: friends and translations; and (3) James in Spain: translations and readers. A number of names and facts will be mentioned, since they provide the general framework for understanding the reception of William James in Continental Europe, but in particular the personal relations between William James and some of the most relevant European thinkers of his time are highlighted.

\section{AUTHOR}

JAIME NUBIOLA

Universidad de Navarra

jnubiola[at]unav.es 